\title{
EDUCATION OF FARMERS IN THE FIELD OF SUSTAINABLE DEVELOPMENT IN THE DAIRY INDUSTRY IN POLAND
}

\author{
Ewa Stawicka ${ }^{1}$, Phd; Agnieszka Werenowska ${ }^{2}$, Phd and Ewa Jaska ${ }^{3}$, Phd \\ $1,2,3$ Warsaw University of Life Sciences (WULS-SGGW)
}

\begin{abstract}
The paper addresses the problem of challenges posed by the global market in the field of sustainable development objectives and the enterprises' ability to achieve them. The leading entrepreneurs are developing increasingly innovative and original socially responsible strategies. At the same time, entrepreneurs who do not create long-term strategies are lagging behind. The paper discusses corporate social responsibility on the food market, and more precisely on the dairy market. The analysis covered socially responsible activities undertaken by dairy companies from the Top 10 list. Particular attention has been paid to the crucial link in a supply chain dairy farmers. Nowadays, consumer surveys show that, when it comes to dairy companies, they care where the milk comes from and how it is produced, how the cows are treated and how the company engages in cooperation with suppliers. There are companies on the dairy market in Poland who have launched a strategic approach to CSR a long time ago by implementing many innovations in creating a competitive advantage on the market. There are companies who have successfully adapted to changes and also those that cannot combine economic, social and environmental goals. The study aims to make a contribution to further detailed research on creating competitive advantage based on sustainable business models in dairy enterprises.
\end{abstract}

Key words: education, farmer, milk producer, sustainable development

JEL code: A13, Q18.

\section{Introduction}

The Sustainable Development Goals (SDGs) announced by the UN comprise new tasks and strategic cooperation between various stakeholder groups. Actions aimed at achieving the objectives of sustainable development create the opportunity to build a sustainable competitive advantage (Bocken, Short, Rana, Evans, 2014). One of the sources of competitive advantage, beyond reputation, is the development of innovative products and services that respond to the needs of more informed and responsible consumers. The agri-food sector is one of the key areas where sustainable development is of particular importance. The global demand for food products has been on the rise in recent years. The dairy market is becoming an increasingly demanding food market. There is a decline in the prices of both strategic products, e.g. butter as well as sour milk products (e.g. yoghurts). The prices of dairy products are decreasing on all world commodity markets. This trend generates increased competition and encourages companies to offer more and more "transparent" products to meet the demand of consumers who are prepared to pay more for responsible business practices (portal spozywczy.pl, update date 02/02/2019). According to A. Parzonko (2010) the promoted sustainable development of agriculture remains, to some extent, in opposition to the actual economic reality. Since 2004 farms in Poland have transformed in the direction of deeper specialization and agricultural production of one type tended to concentrate in a given region. Looking through the prism of sustainable development, these changes may not be beneficial, especially in the environmental dimension. The traditional understanding of the sustainability of agricultural production is defined with regard to securing food supplies and the impact of agriculture on the preservation of natural resources (Zegar, 2009). The challenge for the agri-food economy is therefore such sustainable development, which involves management methods ensuring simultaneous implementation of production, economic, ecological and social goals (Runowski, 2004). It also turns out that the announced Sustainable Development Goals (SDG) require new strategic actions from

\footnotetext{
${ }^{1}$ Corresponding author. E-mail address:ewa_stawicka@sggw.pl

2 Corresponding author. E-mail address:agnieszka_werenowska@sggw.pl

${ }^{3}$ Corresponding author. E-mail address:ewa_jaska@sggw.pl
} 
enterprises and cooperation between various stakeholder groups. In the context of SDG and corporate social responsibility, attention is paid to improving the competitiveness of the agri-food sector, sustainable development of rural areas, a sustainable supply chain, improvement of the natural environment, improvement in life quality and diversification of rural economy (Stawicka, 2015). The creation of business strategies has become characteristic of Polish dairy enterprises. Over the last few years, a number of innovations involving automation and robotics have been implemented and the milk yield of dairy cows has significantly improved. Despite the difficulties on the global milk market, specific, innovative and responsible practices ensure the development of entities involved in the production, processing and trading of milk and milk products.

The key challenges in implementing business strategies and sustainability goals include the quality of human resources, knowledge and financial resources. The need for changes is related to effective knowledge transfer, implementation of modern technologies and change in attitudes.

The aim of the study was to characterize the implementation of socially responsible strategies in dairy enterprises of various organizational and legal forms with particular focus on one of the elements of the strategy which is the education of dairy farmers (as the main stakeholders in the supply chain). The study attempts to present the processes of shaping attitudes, broadening knowledge and implementing innovations in the case of dairy farmers, who cooperate with dairy enterprises. The research analysis covers dairy companies from the "Top 10" list with the focus on their policies regarding shaping attitudes and education of farmers cooperating with dairies.

The paper aims to make a contribution to further research on the strategy of dairy enterprises in creating a competitive advantage, including cooperation and participation of stakeholders in the process of a sustainable supply chain. The results of the analyses were presented in graphical and tabular form.

\section{Development trends on dairy market in Poland}

In Poland, the region with the longest dairy traditions is Podlaskie, and the dairy leaders are Mlekovita (based in Wysokie Mazowieckie) and Mlekpol (based in Grajewo). Also the district dairy cooperative Piątnica has roots in Podlaskie region and, like the two previous cooperatives, is a dairy leader. The large dairy sector entities also include Polmlek, Lacpol, Spomlek, Sierpc, Kolo, Gostyn and companies with foreign capital such as Danone or Hochland. Podlaskie is the place of origin for numerous cheeses included in the List of Traditional Products held by the Ministry of Agriculture. The list includes e.g. Hajnowski curd cheese, Swiss type cheese from Wizajny and local cheese from Korycin. The processing plants from Podlaskie, along with offering traditional specialties, also launch innovative products. Mlekpol produces lactose-free yoghurts and Mlekovita, which offers over 800 products, is the only dairy company in Podlaskie which produces ice cream on an industrial scale. Only in 2015 Mlekovita launched 116 new dairy products (mleczarstwo.com).

Since the beginning of the 1990s, the leader of the CSR practices in the dairy industry on the Polish market was Danone Mlekovita, on the other hand, has become the leader on the dairy market since about 2014. At present, Mlekovita owes its strong position to a large number of acquisitions and it now has 19 production plants. Mlekpol has only 4 plants less. In 2017, the top places in the Top 10 ranking were taken by Mlekovita, Polmlek, Mlekpol, Lowicz, Lacpol, Piatnica, Spomlek, Kolo, Lactalis, and Gostyn (Figure 1). 


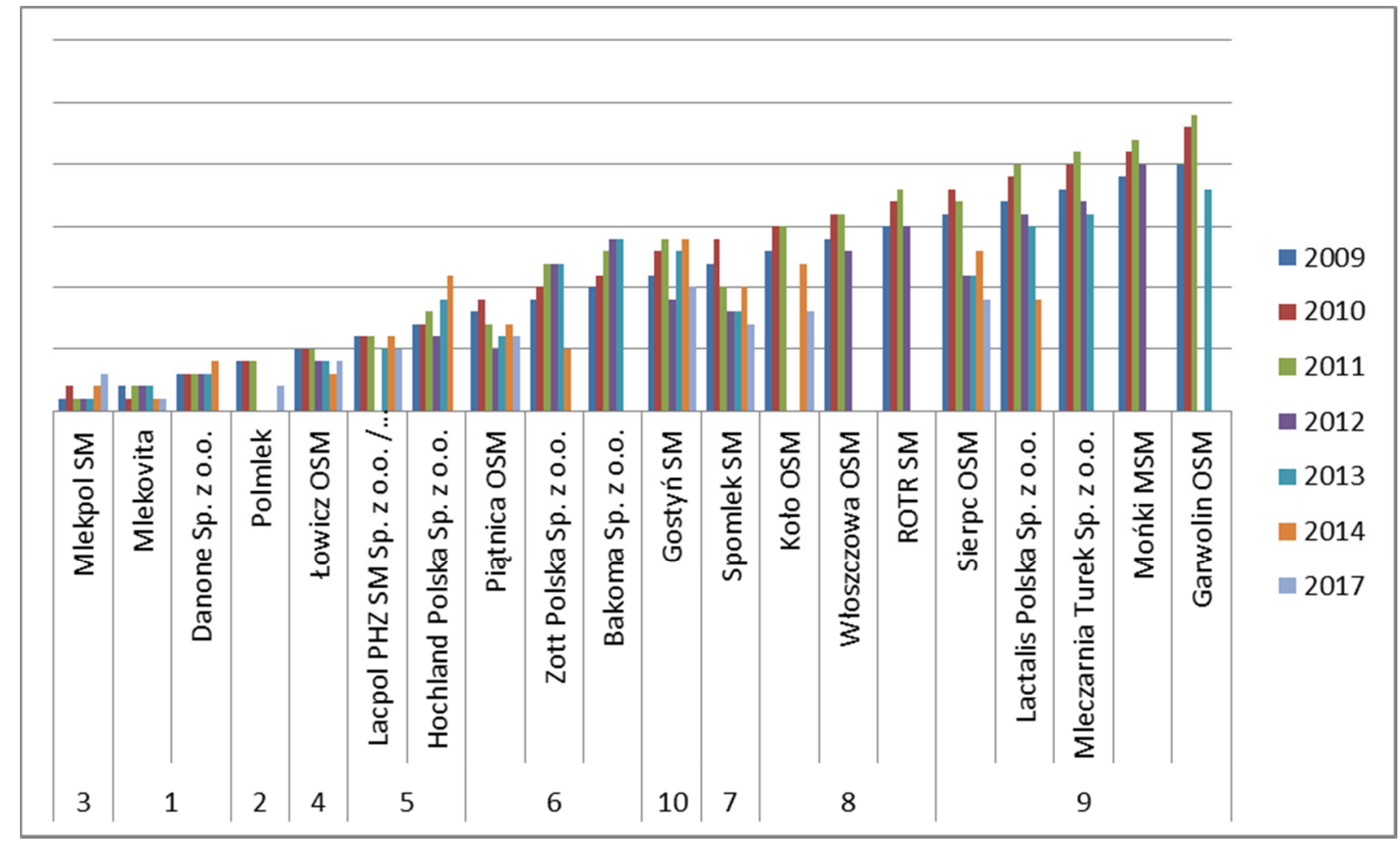

Source: author's calculations based on portalspozywczy.pl, updated on 31 January 2019

Fig. 1. Top 10 dairy producers in Poland in 2009 - 2017

It seemed that Polish dairy cooperatives will not be able to beat off fierce competition from Danone, Dr. Oetker or Hochland. However, since 2004, after Poland's accession to the EU, dairy plants have turned out to be a phenomenon, and it is the global producers with foreign capital who are now in trouble. They have been taken over or pushed out of the market by Mlekovita, Mlekpol and Polmlek, whose total revenues have already exceeded 10 billion PLN (mlekovita.com.pl).

When in 1992 Danone appeared on the Polish market, it focused on developing good practices in the field of sustainable development and CSR. Its strategy covered such areas as:

- economic impact on local communities through the purchase of milk, raw materials and packaging

- preventing environmental pollution, feeding animals with appropriate forage, paying attention to the harmful effects of methane;

- environmental and ecological impact, responsible and economical approach to water and energy consumption;

- facilitating employees' professional development, creating a friendly organizational culture, securing regular payments for farmers and development assistance for suppliers;

- responsible transport, e.g. wall to wall factory, (e.g. packages for Actimel series products are produced next to the yogurt production site); planning transport routes to reduce the number of kilometres travelled, optimizing the loading of goods so that No space is wasted in vehicles;

- measurable and documented results of reduction of water and energy consumption, creation of a new environmental strategy. Danone initiated the cooperation approach to the so-called a new generation of farmers (Danone report, 2018).

It is difficult to assess to what extent these practices have also influenced the functioning of Polish dairy cooperatives, which are now economically successful. Their success may be attributed to the quality of Polish milk, but also to the responsible practices of dairy cooperatives towards the stakeholders - primarily dairy farmers. 
For example, the Sierpc cooperative pays particular attention to the quantity and quality of protein in milk bought from farmers. The cooperative encourages, educates and supports farmers - "we reward farmers for the quality of milk" (osm-sierpc.pl). Mlekpol from Grajewo (mlekpol.com.pl) successfully launched the very popular "Laciate”("Spotted”) milk. Mlekovita, in reaction to consumers' frequent health concerns, developed a range of milk products without lactose (mlekovita.com.pl). Dairy companies strongly emphasize CSR practices, but they mainly regard their product offer. This is evidenced by the diversity of offering and attempts to get in new markets, e.g. OSM Koło received HALAL certificate for milk powders and butter (osmkolo.pl). Spomlek, on the other hand, wants to function in the HoReCa (food and beverage service) trade channel. They offer cheeses for cheese boards served in hotel restaurants. Spomlek seeks the recommendations of the best cooks and chefs for its cheeses. According to experts, Amber, Rubin and Szafir are the best Polish longripening cheeses. They are created in Radzyn Podlaski under the supervision of experienced cheese makers, according to recipes developed over 15 years ago (spomlek.pl). An interesting product innovation is Skyr offered by OSM Piatnica - an Icelandic yoghurt produced according to traditional recipe, which gained popularity in Europe and the United States. The product is characterised by high protein content and zero fat. It is particularly popular with consumers leading an active and healthy lifestyle. The cooperative from Piatnica offers this yoghurt in four flavour versions, as well as Skyr natural (piatnica.com.pl). Another project, aimed to reward the high quality milk from dairy farmers and their individual approach to achieving sustainable goals is the "Farm of the Year" competition. It is a flagship initiative of Spomlek dairy cooperative which is supposed to reward the most modern and most prosperous farms. The competition emphasizes the aspect of a sustainable supply chain and the success of the dairy plant in cooperation with farmers and suppliers. During the gala, farmers cooperating with the company are awarded prizes to for their breeding work, production dynamics and delivery of the highest quality raw material. The winners receive the "Farm of the Year" titles and the main prizes - yellow and spotted Skoda cars resembling "Serenada" cheese produced by Spomlek (spomlek.pl).

There are also changes in Polish dairy cooperatives' exports. For example, Mlekpol exports a significant part of its production, sending its products to almost all countries in the world. They can be found on the shelves in shops in the European Union countries, mainly Italy, France, Germany, the Netherlands, Belgium, Spain, Czech Republic and Great Britain as well as to Africa and the Far East. The export offer includes hard cheeses, skimmed milk powder, butter and whey powder (IERiGZ-PIB, 2017).

Social responsibility as part of sustainable development is becoming an increasingly common practice in the dairy industry, which stimulates high quality and innovation to meet the growing needs of stakeholders. The number of innovative ideas implemented by dairy companies is growing. They actively work out CSR strategies which engage farmers in the process of knowledge exchange and decision making. The actions of stakeholders and the exchange of knowledge lead to gaining competitive advantages on the market. These practices increasingly result in growing exports and determine a competitive advantage also in the global market. 


\section{Sustainable Agriculture Program - transfer of knowledge and education to the agricultural practice of dairy farmers}

All the above-mentioned successes in the dairy industry originate in the "new times" strategies, which involve sustainable supply chain management and enhancing milk quality, where a key role is played by farmers who supply milk to dairy plants.

An example of a Sustainable Development Plan (SDP) is the strategy developed by Danone. The SDP program is a concept of milk production development that combines economic, social and quality objectives with environmental requirements and caring about the wellbeing of future generations. The SDP program is a pioneering initiative of Danone. Research shows that consumers increasingly care about the quality of milk: where it comes from, how it is produced, how cows are treated, and whether the company engages in cooperation with suppliers. The plan consists of seven pillars implemented through individual operational strategies. To achieve the assumed objectives Danone holds regular workshops and trainings for farmers, developed a website for milk suppliers emilka.danone.pl and encourages contact via e-mail and telephone. Seminars concerning quality standards and production specifics are organized for farmers and suppliers. The seminars also include visits to the factory, discussions and sharing good practices regarding e.g. quality of milk, which in $70 \%$ depends on the conditions in which cows live. Danone is an example of a company facilitating constant cooperation with farmers and their education. In total, Danone cooperates with 350 farmers who have 17000 cows. Farms are constantly monitored by independent laboratories and farmers are supported with free consultations of zootechnicians. Danone also supports many farms financially by providing loans to farmers buying equipment or heifers. Farmers also participate in trainings on environmental protection, programs aimed at reducing water and energy consumption and limiting the use of plant protection products (Danone Reports, 2006-2009, 2010-2012, 2017).

High standards are required from farmers but they are also trained to meet them. Danone builds long-lasting and stable relations with farmers, which ensure the continuity of deliveries and timely financial settlements. All these activities also result in improving the life quality in the countryside and production of healthier and safer products.

Intensive cooperation with farmers is not just the domain of Danone. Other dairy enterprises are also increasingly involved in educating and motivating farmers with regard to responsible practices. Dairy companies often reward farmers mainly for high quality milk, (although, there are cooperatives which put quantity ahead of quality). Global trends and sustainable development involve more demanding consumers, who pay attention to aspects other than just price and want to gain knowledge about the method of milk production. The price for $100 \mathrm{I}$ of milk is on the rise and in 2017 it amounted to 138.62 PLN. This is related to the increase in the number of cows (Rynek mleka, 2018).

Farmers' education, automation and robotics, as well as other innovations in the dairy industry, improve cow milk yield (Table 1 ).

To a large extent, Polish farmers themselves observe the market trends and seek knowledge in the field of dairy cattle breeding. The high quality of Polish milk is also confirmed by the VLOG certificate, which is more and more often awarded to Polish farmers. The first VLOG certificate in Poland was held by Hochland, and Strzelecka Spoldzielnia Producentow Mleka (cooperative of milk producers) is the second entity in the Polish dairy sector, holding the "non GMO" certificate for compliance with the VLOG standard (bureauveritas.pl). This is the result of cooperation between 
Polish farmers and the dairy industry aimed at transparent milk production in accordance with sustainable development trends.

\section{Milk yield of cows and number of cowsheds by province in 2017}

\begin{tabular}{|l|l|c|c|}
\hline No & \multicolumn{1}{|c|}{ Province } & $\begin{array}{c}\text { Milk yield } \\
\text { (kg of milk } \\
\text { per year) }\end{array}$ & $\begin{array}{c}\text { Number } \\
\text { of } \\
\text { cowsheds }\end{array}$ \\
\hline 1. & Pomorskie & 7850 & 989 \\
\hline 2. & Zachodnio-pomorskie & 8443 & 265 \\
\hline 3. & Warminsko-mazurskie & 7725 & 1564 \\
\hline 4. & Podlaskie & 7986 & 4111 \\
\hline 5. & Kujawsko-pomorskie & 8360 & 1648 \\
\hline 6. & Mazowieckie & 7902 & 4045 \\
\hline 7. & Lubuskie & 9022 & 82 \\
\hline 8. & Wielkopolskie & 8725 & 3434 \\
\hline 9. & Lodzkie & 7887 & 1462 \\
\hline 10. & Lubelskie & 8116 & 1081 \\
\hline 11. & Dolnoslaskie & 9001 & 211 \\
\hline 12. & Opolskie & 9056 & 287 \\
\hline 13. & Slaskie & 9002 & 318 \\
\hline 14. & Swietokrzyskie & 7630 & 265 \\
\hline 15. & Malopolskie & 5962 & 697 \\
\hline 16. & Podkarpackie & 6127 & 323 \\
\hline
\end{tabular}

Source: based on data from www. regiohurt.pl, PFHBiPM, updated on 25 - January 2019

In Poland, farmers are also increasing their herds of cows. The average herd in 2017 counted 38 cows. The structure of the herds, however, looked as follows:

- up to 9 cows were kept in 839 herds $(-2.6 \%)$;

- from 10 to 19 cows were kept in 4351 herds $(-4.7 \%)$;

- from 20 to 49 cows were kept in 1,1033 herds (+ $0.9 \%)$;

- from 50 to 149 cows were kept in 3366 herds (+10.9\%);

- from 150 to 299 cows were kept in 294 herds $(+3.5 \%)$;

- from 300 to 499 cows were kept in 94 herds $(+1.1 \%)$;

- more than 500 cows were kept in 55 herds $(+5.8 \%)$.

Only 9 herds had more than 1000 cows and in over 300 cowsheds only 6 cows were kept (Ocena i hodowla ..., 2018).

The leaders achieving the best milk yield exceeding $9,000 \mathrm{~kg}$ of milk per cow per year came from the following provinces: Opolskie (9056 kg), Lubuskie (9022 kg), Slaskie (9002 kg), and Dolnoslaskie (9001 kg) (www.topagrar.pl, update date 04/02/2019).

The changes in farmers' attitudes in the field of responsible and sustainable development regard the very approach to cow breeding, effective use of pastures, appropriate organization of grazing, optimal forage feeding and the botanical composition of the pasture.

There are more and more cows that have achieved total production of over $100,000 \mathrm{~kg}$ of milk during their lifetime. The record holder was Doris 129, a cow from the Komorowo farm (Kujawskopomorskie province), which for 12 years produced $169327 \mathrm{~kg}$ of milk (Ocena i hodowla..., 2018).

Farmers in accordance with the trends of sustainable development more and more often meet the highest EU standards in terms of dairy cattle breeding and milk quality. The cowsheds have improved significantly and are now adequately equipped, well-ventilated and illuminated. The feeding of cows 
is monitored; the forage is specially composed and prepared. The welfare of cows, health and safety at work as well as the economic development of farms with regard to the protection of the environment are improving. However, these practices are not applied on all dairy farms. Sustainable agriculture is not a common phenomenon on farms. The problem is insufficient financial resources and often lack of up-to-date know-how and innovation both on farms and in cooperating dairy plants. Social responsibility aspect differs depending on the company's legal ownership. Companies with foreign capital and dairy cooperatives demonstrate a wide variety of practices ensuring the participation of farmers and suppliers. Multinational enterprises dominate with regard to better change management in the CSR and SDP strategies, preparing social reports and communicating good practices.

\section{Conclusions, proposals, recommendations}

1) The biggest changes related to CSR and the development of Polish companies in the dairy industry appeared after Poland's accession to the European Union. This is, among others, the result of more intensive actions undertaken in the field of farmers' education and shaping attitudes towards sustainable development of agriculture.

2) When analysing dairy plants from the TOP10 list one may identify various CSR practices and be able to either directly or indirectly determine the business model of the enterprises. On the other hand, the practices of Danone or Hochland are a transformational model and set an example of involving farmers in knowledge sharing process in order to disseminate the idea of sustainable development.

3) The assumptions of the sustainable development program are particularly promoted by Danone and are aimed at long-term and stable development of farms, in particular ensuring cow's wellbeing and production of high quality milk, economic development of farms, occupational safety and health, rural community development and actions for the protection of environment.

4) Although all dairy plants declare to a greater or lesser extent the policy of sustainable development and CSR, it very often focuses on the product offer and highlighting high quality. CSR is still reduced to marketing and sponsoring activities. The dairy enterprises, despite meeting quality criteria, are not fully responsible and transparent in their practices.

\section{Bibliography}

1. Bocken, N.M.P, Short S.W, Evans S., A Literature and Practice Review to Sustainable Business Model. Journal of Cleaner Production 65 (2014) 42-56.

2. Parzonko, A. (2010). Globalne i lokalne uwarunkowania rozwojuprodukcji mleka [Global and local determinants of milk production development]. Wydawnictwo SGGW, p. 8.

3. Runowski, H. (2004). Zrównoważony rozwój gospodarstw i przedsiębiorstw rolniczych [Sustainable development of agricultural holdings and entreprises. (In: ) M. Klodzinski (Ed.), Gospodarka, człowiek, srodowisko na obszarach wiejskich [Economy, man and the environment in rural areas], IRWiR PAN, pp. 224-238.

4. Stawicka, E. (2015). Społecznie odpowiedzialne praktyki rynkowe przedsiebiorstw w obszarze relacji z konsumentami [Socially responsible market practices of enterprises in the area of consumer relations]. Journal of Agribusiness and Rural Development, No. 3, pp. 539-545.

5. Zegar, J. (2009). Z badan nad rolnictwem społecznie zrownowazonym [10]. Raport koncowy, synteza I rekomendacje [Research on socially sustainable agriculture. Final report, synthesis and recommendations]. PW 2005-2009 No. 175. Warszwa: IERiGŻ-PIB, p. 13.

6. IERigZ-PIB, (2016). Rynek mleka, stan i perspektywy [Milk market, state and prospects]. Kwiecien, p. 11.

7. IERigz-PIB, (2017). Rynek Rolny, Analiza, Tendencje, Oceny [Agricultural Market, Analysis, Trends, Ratings]. Biuletyn miesieczny No. 10 (320).

8. Polska Federacja Hodowcow Bydla I Producentow Mleka [Polish Federation of Cattle Breeders and Milk Producers], (2018). Ocena i hodowla bydla mlecznego- Dane za rok 2017 [Evaluation and breeding of dairy cattle - data for 2017]. 
9. www.bureaveritas.pl, update date 02.02.2019

10.www.portalspozywczy.pl/tagi/rynek-mleka, update date 02.02.2019

11. www.topagrar.pl, update date 04.02.2019

12.www. regiohurt.pl, PFHBiPM, update date 25.01.2019

13.www.mleczarstwo.com, update date 25.01.2019

14. Raporty Spoleczne Danone [Danone Social Reports], 2006-2009, 2010-2012, 2018.

15. spomlek.pl, update date 25.01.2019

16. osmkolo.pl, update date 25.01.2019

17. mlekovita.com.pl, update date 25.01.2019

18. mlekpol.com.pl, update date 25.01.2019

19. osm-sierpc.pl, update date 25.01.2019

20. piatnica.com.pl, update date 25.01.2019

21.www.danone.pl, update date 25.01.2019

22. hochland.pl, update date 25.01.2019. 